\title{
Comparative transcriptional profiling analysis of the two daughter cells from tobacco zygote reveals the transcriptome differences in the apical and basal cells
}

Tian-Xiang $\mathrm{Hu}^{\dagger}$, Miao $\mathrm{Yu}^{\dagger}$, Jie Zhao*

\begin{abstract}
Background: In angiosperm, after the first asymmetric zygotic cell division, the apical and basal daughter cells follow distinct development pathways. Global transcriptome analysis of these two cells is essential in understanding their developmental differences. However, because of the difficulty to isolate the in vivo apical and basal cells of two-celled proembryo from ovule and ovary in higher plants, the transcriptome analysis of them hasn't been reported.

Results: In this study, we developed a procedure for isolating the in vivo apical and basal cells of the two-celled proembryo from tobacco (Nicotiana tabacum), and then performed a comparative transcriptome analysis of the two cells by suppression subtractive hybridization (SSH) combined with macroarray screening. After sequencing, we identified 797 differentially expressed ESTs corresponding to 299 unigenes. Library sequence analysis successfully identified tobacco homologies of genes involved in embryogenesis and seed development. By quantitative realtime PCR, we validated the differential expression of 40 genes, with 6 transcripts of them specifically expressed in the apical or basal cell. Expression analysis also revealed some transcripts displayed cell specific activation in one of the daughter cells after zygote division. These differential expressions were further validated by in situ hybridization (ISH). Tissue expression pattern analysis also revealed some potential roles of these candidate genes in development.

Conclusions: The results show that some differential or specific transcripts in the apical and basal cells of twocelled proembryo were successfully isolated, and the identification of these transcripts reveals that these two daughter cells possess distinct transcriptional profiles after zygote division. Further functional work on these differentially or specifically expressed genes will promote the elucidation of molecular mechanism controlling early embryogenesis.
\end{abstract}

\section{Background}

Embryo development from one-celled zygote to mature embryo is a critical part of the life cycle in higher plants. During double fertilization, one sperm cell from pollen grain fuses with an egg cell from embryo sac, and the resultant zygote undergoes a series of precise cell divisions and develops into an embryo [1,2]. In most angiosperms, the first zygotic cell division is transverse

\footnotetext{
* Correspondence: jzhao@whu.edu.cn

+ Contributed equally

Key Laboratory of the Ministry of Education for Plant Developmental Biology, College of Life Sciences, Wuhan University, Wuhan 430072, China
}

and asymmetric, resulting in the formation of a twocelled proembryo with a small apical cell and a large basal cell. The small apical cell with dense cytoplasm develops into embryo proper, and the large vacuolated basal cell differentiates into hypophysis and suspensor. The hypophysis contributes to the formation of root meristem within the embryo proper [3]. The suspensor, a terminally differentiated embryonic region, connects the embryo proper to the surrounding maternal tissues, serves as a conduit for nutrients and growth regulators supporting embryo development, and degenerates in the late embryo development [4]. In Arabidopsis, the 
mutations of gnom (gn), root-shoot-hypocotyl-defective $(r s h)$ and yoda $(y d a)$ alter the asymmetric division of zygote, and result in the formation of two nearly equalsized daughter cells and subsequent defect of embryonic axis establishment [5-7]. It suggests that the asymmetric division of zygote producing the apical and basal cells is a crucial event of early embryogenesis.

Previous researchers adopted various techniques and experiment systems to investigate embryogenesis mechanism. In lower plant, the zygote and embryo of brown alga (Fucus) have long been served as a cellular model to investigate early embryogenesis because of their development free of maternal tissue [8-10]. However, embryo sac in higher plants is typically surrounded by the sporophytic tissues of ovule and ovary, thus access to the embryo is hampered. To overcome these difficulties, the researchers utilize some in vitro culture systems to study the early embryo development mechanism [11-15]. Compared with embryogenesis in vivo, there are some differences in the way of embryos originate and develop, therefore, the results obtained in vitro fail to explain all the questions.

Since specific gene expression is usually linked directly to different developmental process, many techniques are exploited to identify genes expressed in the developing embryo, including cDNA library construction [16], promoter/enhancer trapping [17] and mutational screens $[18,19]$. Several embryo essential genes, such as gn, twin $(t w n)$, monopteros (mp), bodenlos (bdl), topless ( $t p l)$ and $y d a$, were successfully identified by the mutant analysis in Arabidopsis [6,7,20-23]. cDNA libraries from complex tissues such as ovule are not efficient in identifying genes expressed at low level or only in the early severalcelled proembryos. Recently, the development of laser capture microdissection (LCM) makes it possible to analyze the transcriptional profiles in specific embryo domains $[24,25]$, but the single egg cell, zygote or early several-celled embryo are still too small to be isolated. Fortunately, micromanipulation, a powerful skill, is used successfully to isolate single cells from the embryo sac of some species such as maize, barley, tobacco, wheat and rice [11,26-29]. This technique combined with the transcriptome assay broadens our knowledge of gene expression in egg cell, central cell, zygote and proembryo [30-34], and these valuable information help us to understand certain critical questions such us zygote gene activation in higher plants.

Some genes up- or down-regulated in the two daughter cells from in vitro fertilized maize zygote were identified by Okamoto et al. [35]. However, besides the difference of embryogenesis in vitro and in vivo, there are even greater differences between embryo development in monocotyledon and dicotyledon plants. In contrast with the fixed and traceable division pattern during early embryogenesis in classic dicotyledon plants, variant cell division occurs during the proembryo development of monocotyledon plants [36]. Up to now, the analysis of transcriptional profiles in the in vivo apical and basal cells from the two-celled proembryo in dicotyledon plants is not reported. Therefore, in the present study, we focused on the transcriptome differences between the two cells in dicotyledonous plant tobacco. We originally established a procedure for isolating the live apical and basal cells of the in vivo two-celled proembryo just after the first cell division of zygote, and then the SMART PCR synthesized cDNAs from these two cells were used for SSH analysis. After macroarray screening and sequencing of the candidate clones, we successfully identified 797 ESTs that were specifically or predominantly expressed in the apical or basal cells. The ESTs were further analyzed, including comparative studies on the different transcript composition, functional classification, and validation by real-time PCR and in situ hybridization in the zygote and its apical and basal daughter cells. Also, the expression patterns of some identified ESTs were analyzed in different organs and tissues. The transcriptional composition differences in the apical and basal cells and possible function of some candidate differential transcripts are further discussed.

\section{Results}

Establishment of isolation procedures for the apical and basal cells from the two-celled proembryo

A well established method based on enzymatic maceration combined with brief micromanipulation [12] allowed us to isolate enough two-celled proembryos (Figure 1a, g, h). To study the transcriptome differences of the apical and basal cells, we established a procedure to get the separated protoplasts. Based on the enzyme mixture from Okamoto et al. [35], we optimized the key factors including incubation temperature and time for enzyme treatment of the two-celled proembryos to separate the apical and basal cells and preserve their viability under sterile environment. Incubation in $25^{\circ} \mathrm{C}$ for 15 min was tested to be the most suitable conditions for the isolation of the two cells. To avoid confusing the apical and basal cells from different proembryos, each proembryo was digested in an individual droplet of enzyme solution. The intact isolation process was shown in Figure 1g-j. After incubation, a pair of living protoplasts from the small apical cell and the large basal cell (Figure 1i, j) was isolated and then collected respectively (Figure 1c, e). The bright fluorescein diacetate (FDA) fluorescence emitted from the protoplasts indicated their strong viability (Figure 1d, f). Two transcription inhibitors, actinomycin D and cordycepin were added in the solutions to inhibit gene expression in response to possible stresses during the isolation process. 

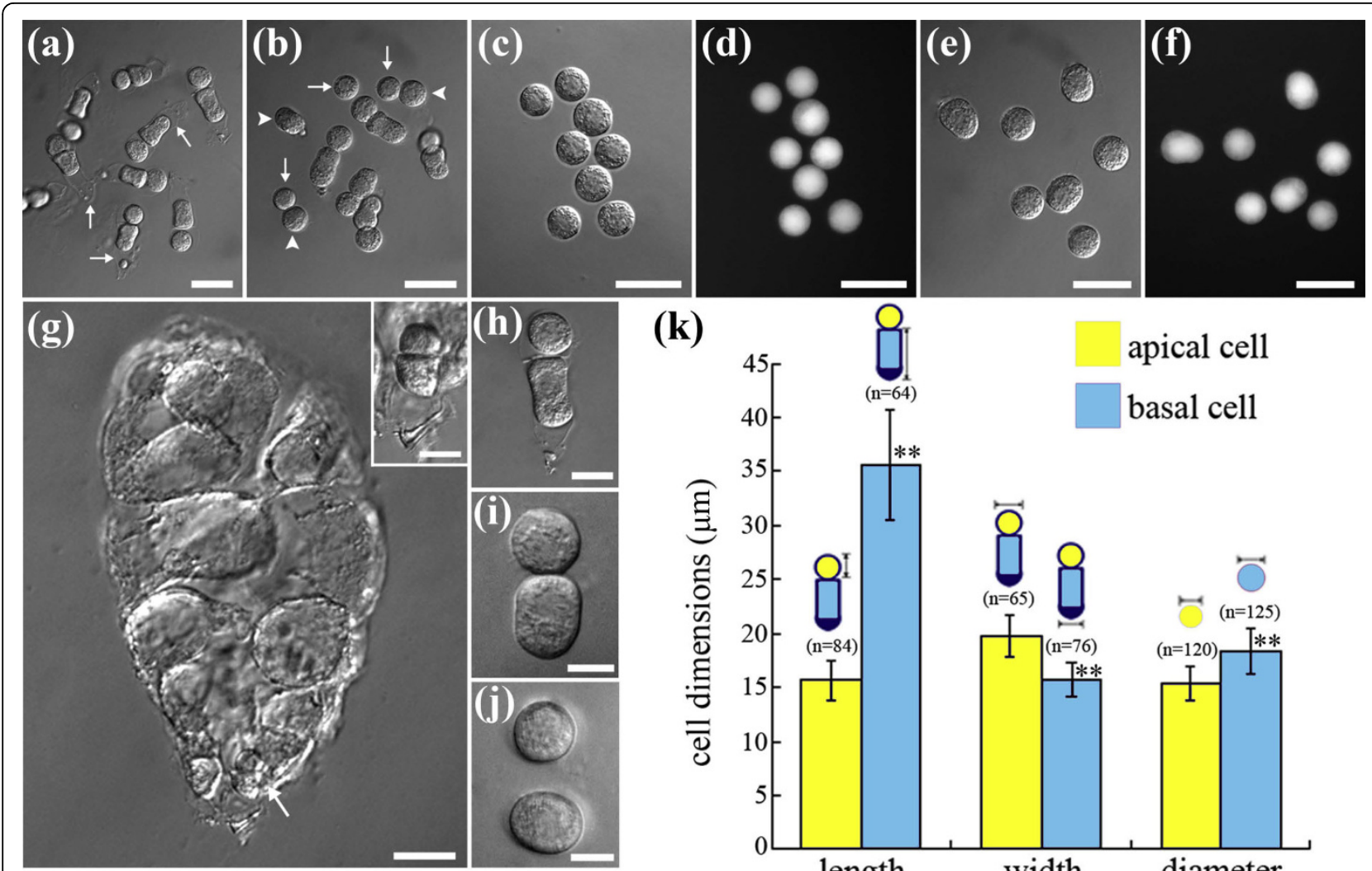

(k)

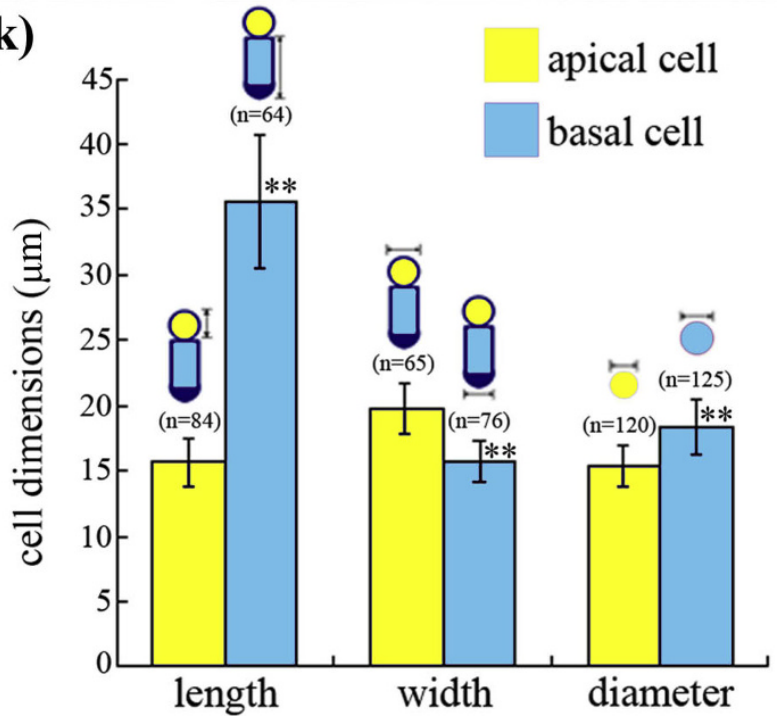

Figure 1 Isolation of the two-celled proembryos and protoplasts of the apical and basal cells in tobacco. (a) Freshly isolated two-celled proembryos with cell wall (arrows). (b) Two attached protoplasts derived from cell wall-digested two-celled proembryo. The small (arrows) and large protoplasts (arrowheads) are derived from the apical and basal cells of the two-celled proembryos, respectively. (c) Small living protoplasts from the apical cells. (d) Fluorescent image of the same protoplasts in (c), stained with FDA. (e) Large living protoplasts from the basal cells. (f) Fluorescent image of the same protoplasts in (e), stained with FDA. (g) One fertilized embryo sac with a two-celled proembryo (arrow) and a lot of endosperm cells. Inset is a magnification of the two-celled proembryo in embryo sac. (h-j) The detailed isolation process of a pair of protoplasts from a two-celled proembryo in an individual droplet. ( $\mathrm{k}$ ) Cell size of the apical and basal cells, and diameter of the protoplast from the in vivo two-celled proembryos. Bars in ( $k$ ) show the mean \pm standard error (SE), and " $n$ " means the number of measured cells. Bar $=30 \mu m$ in Figure a-g; Bar $=15 \mu \mathrm{m}$ in Figure $\mathrm{h}$ and inset; $\mathrm{Bar}=10 \mu \mathrm{m}$ in Figure i and $\mathrm{j}$. ${ }^{*}$ Significant difference at $\mathrm{P}<0.01$.

After the first zygotic division, tobacco zygote produces two asymmetric daughter cells just like most classic dicotyledonous plants. Morphologic observation of the isolated two-celled proembryoes revealed that the shape and size of apical cell is distinct from those of the basal cell. As shown in Figure 1h, the apical cell is small and nearly spherical, whereas the basal cell is relatively large and elongated. To epitomize the cell size differences between the two cells, we measured cell length in vertical axis, width in transverse axis as well as the diameters of the two protoplasts (Figure 1k). The results show that the ratios of the basal cell to the apical cell are 2.28 in length and 0.80 in width, and the diameter of basal cell protoplast is larger than that of apical cell, with $18.37 \pm 2.05 \mu \mathrm{m}$ versus $15.41 \pm 1.54 \mu \mathrm{m}$. To display the distinct difference in size, several couples of the isolated apical and basal cells were shown in the same bright field (Figure 1b).

\section{cDNA synthesis and identification of differentially} expressed genes between the apical and basal cells

About three hundred pairs of apical and basal cells from the two-celled proembryos were isolated and collected respectively for RNA isolation. The first-strand cDNA was synthesized by applying a template-switch mechanism to the 5'end of the RNA template (SMART) during reverse transcription and then amplified by long-distance PCR (LD-PCR). After the optimization of PCR cycle number, all amplification of sample cDNA was then carried out for 23 PCR cycles. Generally, the final cDNA products from both types of cells mainly distributed from $0.5 \mathrm{~kb}$ to $4 \mathrm{~kb}$ in gel electrophoresis, with nearly equal distribution over the whole size range (Figure 2a).

To reveal the transcriptome differences of the apical and basal cells, suppression subtractive hybridization (SSH) was applied to identify the differentially expressed 


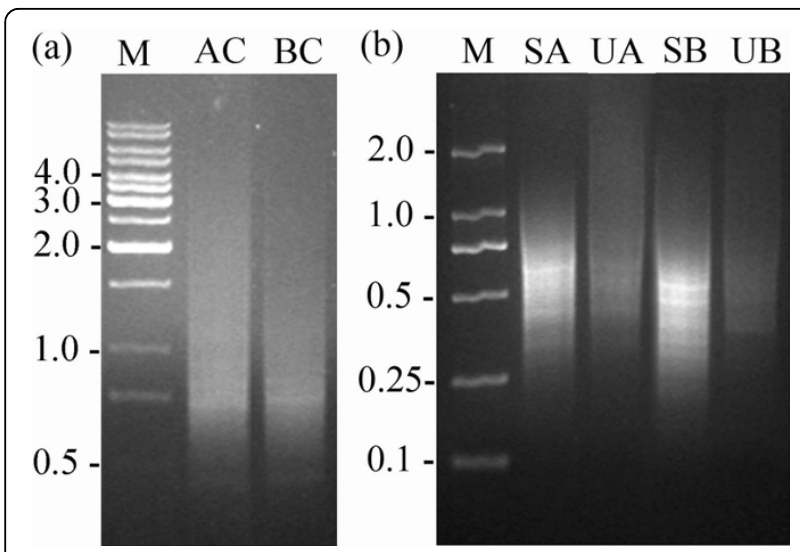

Figure $2 \mathrm{Gel}$ electrophoresis images of CDNA from the apical and basal cells of tobacco two-celled proembryo by LD-PCR and products of PCR-select CDNA subtraction. (a) CDNAs synthesized from the apical cell (AC) and basal cell (BC). M, Molecular marker 1 kb DNA ladder. (b) Products of PCR-select CDNA subtraction. M, Molecular marker DL2000; SA, the second PCR product of the apical cell/basal cell subtraction; UA, the second PCR product of the unsubtracted control; SB, the second PCR product of the basal cell/apical cell subtraction; UB, the second PCR product of the unsubtracted control.

genes. Both forward (apical cell/basal cell, apical cell cDNA as tester) and reverse (basal cell/apical cell, basal cell cDNA as tester) subtracted cDNA libraries were constructed to enrich the genes specifically or predominantly expressed in the apical or basal cells. Pools of putative differentially expressed cDNA were obtained after two rounds of subtraction. Compared with their respective unsubtracted control, both the subtracted DNA samples displayed a quite different distribution with a number of distinct bands. The forward subtracted cDNA ranged mainly from $\sim 300 \mathrm{bp}$ to $\sim 1 \mathrm{~kb}$ and the reverse subtracted cDNA from $\sim 250$ bp to $\sim 750$ bp (Figure 2b).

\section{Bioinformatic analysis of ESTs}

After two rounds of differential screening, the candidate clones were selected for sequencing. Then a total of 797 ESTs sequences, 385 for the apical cell (with library ID AC001C- 385C) and 412 for the basal cell (with library ID BC001C-412C) were generated. The 797 sequences were clustered and assembled into 91 contiguous sequences (contigs; Additional file 1) and 208 single sequences (singletons), with 43 contigs (with library ID ACC01-43) and 124 singletons from the apical cell, and 48 contigs (with library ID BCC01-48) and 84 singletons from the basal cell. Therefore, these 797 ESTs represented 299 unique transcripts. Further BLASTX analysis showed that 131 apical cell transcripts $(78.4 \%$ of apical cell transcripts) and 78 basal cell transcripts (59.5\% of basal cell transcripts) matched significantly ( $E$-value
$<10^{-5}$ ) to database entries with assigned identities, which mainly generated from different tissues of grape, tomato, Arabidopsis, tobacco and rice. The 91 apical and basal cell contigs that consist of two or more ESTs are respectively shown in Table $1 \mathrm{a}$ and $1 \mathrm{~b}$, and the detailed blast annotations of all unigenes are listed in Additional file 2. According to BLAST annotation, the functional role for each transcript is assigned on the basis of sequence similarity to proteins with known functions in GenBank. The classification results according to 13 major functional categories are shown in Figure 3, and the detailed classification of each unigenes is listed in Additional file 2. Transcripts related to protein synthesis and cell structure represent the largest group of transcripts with known function in the apical cell, and both compose of $20.36 \%$ of the apical cell unigenes. In the basal cell, transcripts related to protein synthesis and cell structure also are present with high percentage, followed by related to metabolism, protein fate and disease/defense. The transcripts related to metabolism and disease/ defense compose of $8.40 \%$ and $5.34 \%$ of the total basal cell unigenes, respectively. Besides, $21.56 \%$ apical cell and $40.46 \%$ basal cell transcripts show no significant homology to public databases (Figure 3). This suggests that the apical and basal cell libraries in tobacco are highly effective for identifying transcripts that putatively encode novel proteins.

The subtracted apical and basal cell cDNA libraries provide a resource for identifying genes that involved in embryogenesis. To test the speculation, a BLASTX search was performed to identify genes involved in Arabidopsis embryo development in the subtracted cDNA libraries. The result of search (with cutoff e-value of $\leq 10^{-5}$ ) showed that 12 transcripts in our libraries encoded putative homologies involved in embryo development, with 11 of them similar to $E M B$ genes (Table 2 ). Based on sequence conservation, the biological functions of these tobacco homologies are possibly similar to those of Arabidopsis genes, however, the illustration of their detailed function in tobacco embryogenesis still need further research.

\section{Validation of the differential expression in zygote and its two daughter cells}

To validate the differential expression revealed by macroarray, we used quantitative real-time PCR to detect the differential expression of 40 candidate transcripts (Figures 4 and 5). As no tested gene displayed consistent expression across the samples, none of these genes was selected as internal control. Therefore, we taken the expression levels of candidate genes in zygote as reference with the default value 1 , and then calculated the relative expression levels in the apical and basal cells. The results showed that all the tested 
Table 1 Functional annotation of the differentially expressed contigs with two or more ESTs between the apical cells (a) and basal cells (b)

\begin{tabular}{|c|c|c|c|c|c|}
\hline ID & EST Number & BLASTX sequence similarity ( ${ }^{\text {a }}$ lastN) & Organism & Accession & E-Value \\
\hline \multicolumn{6}{|c|}{ (a) Apical cell } \\
\hline ACC01 & 32 & hypothetical protein & R. communis & XP_002531967 & $4.95 \mathrm{E}-14$ \\
\hline ACCO2 & 32 & unknown protein & G. $\max$ & ACU24256 & 1.07E-19 \\
\hline ACCO3 & 30 & hypothetical protein & V. vinifera & CAN70790 & $1.53 \mathrm{E}-25$ \\
\hline ACCO4 & 17 & hypothetical protein & N. tabacum & YP_173374 & $2.03 E-35$ \\
\hline ACC05 & 14 & cytochrome P450 like protein & N. tabacum & BAA10929 & $2.32 \mathrm{E}-58$ \\
\hline ACC06 & 14 & histone h3 & Z. mays & ACG25088 & $4.31 \mathrm{E}-27$ \\
\hline ACCO7 & 10 & histone h2a & N. tabacum & BAC53941 & $3.89 E-39$ \\
\hline ACC08 & 8 & 40s ribosomal protein $s 23$ & S. tuberosum & ABB16993 & $1.83 \mathrm{E}-76$ \\
\hline ACC09 & 7 & histone h2a & N. tabacum & BAC53941 & 7.74E-38 \\
\hline ACC10 & 6 & histone h2a & S. melongena & BAA85117 & $8.24 \mathrm{E}-26$ \\
\hline ACC11 & 5 & b-type cyclin & R. communis & XP_002530166 & $3.21 \mathrm{E}-14$ \\
\hline ACC12 & 5 & lipid transfer proteins related & V. vinifera & XP_002281585 & $9.59 \mathrm{E}-47$ \\
\hline ACC13 & 4 & dehydrin & N. tabacum & BAD13499 & $2.52 \mathrm{E}-27$ \\
\hline ACC14 & 4 & histone h3 & B. floridae & XP_002595193 & $4.18 \mathrm{E}-26$ \\
\hline ACC15 & 4 & histone h4 & E. japonica & ACX50406 & $1.71 \mathrm{E}-38$ \\
\hline ACC16 & 4 & atp-dependent helicase & V. vinifera & XP_002277541 & $7.63 \mathrm{E}-24$ \\
\hline ACC17 & 3 & $3^{\prime}-5^{\prime}$ exonuclease & V. vinifera & XP_002277523 & $1.15 \mathrm{E}-46$ \\
\hline ACC18 & 3 & calmodulin & S. commersonii & P27161 & $8.15 \mathrm{E}-78$ \\
\hline ACC19 & 3 & cyclophilin & C. annuum & ACB05668 & 7.70E-48 \\
\hline ACC20 & 3 & histone h2a & S. melongena & BAA85117 & $3.49 \mathrm{E}-25$ \\
\hline ACC21 & 3 & histone h3 & M. pusilla & EEH57511 & $7.14 \mathrm{E}-14$ \\
\hline ACC22 & 3 & histone h4 & P. sitchensis & ABK21562 & 7.32E-36 \\
\hline ACC23 & 3 & histone h4 & E. japonica & ACX50406 & $2.75 \mathrm{E}-29$ \\
\hline ACC24 & 3 & histone h4 & E. japonica & ACX50406 & $2.01 \mathrm{E}-38$ \\
\hline ACC25 & 2 & 40s ribosomal protein & S. tuberosum & ABA40465 & $1.04 \mathrm{E}-33$ \\
\hline ACC26 & 2 & 60 s ribosomal protein 123 & T. aestivum & AAP80667 & $1.56 \mathrm{E}-61$ \\
\hline ACC27 & 2 & cytochrome P450 protein & C. lanatus & BAD26579 & $6.95 \mathrm{E}-25$ \\
\hline ACC28 & 2 & histone 2 & V. vinifera & XP_002271506 & $2.52 \mathrm{E}-39$ \\
\hline ACC29 & 2 & histone 2 & V. vinifera & XP_002271506 & $2.62 \mathrm{E}-39$ \\
\hline ACC30 & 2 & histone h2 & G. $\max$ & ACU13572 & $9.67 \mathrm{E}-43$ \\
\hline ACC31 & 2 & histone h3 & Z. mays & ACG25088 & 1.12E-06 \\
\hline ACC32 & 2 & histone h3.3 & S. salar & ACI68311 & $1.83 \mathrm{E}-25$ \\
\hline ACC33 & 2 & histone h4 & E. japonica & ACX50406 & $1.25 \mathrm{E}-35$ \\
\hline ACC34 & 2 & hypothetical protein & V. vinifera & XP_002277580 & $2.19 \mathrm{E}-71$ \\
\hline ACC35 & 2 & hypothetical protein isoform 2 & V. vinifera & XP_002269823 & 1.49E-07 \\
\hline ACC36 & 2 & No hit & & & \\
\hline ACC37 & 2 & polyubiquitin & A. thaliana & AAL09741 & $1.77 E-36$ \\
\hline ACC38 & 2 & ribosomal protein s27 & V. vinifera & XP_002273119 & $9.67 \mathrm{E}-35$ \\
\hline ACC39 & 2 & tabacum cDNA clone mRNA ${ }^{a}$ & N. tabacum & FS383363 & $1.04 \mathrm{E}-140$ \\
\hline ACC40 & 2 & tabacum cDNA clone mRNA ${ }^{a}$ & N. tabacum & AM808955 & $1.55 E-86$ \\
\hline ACC41 & 2 & tabacum cDNA clone mRNA & N. tabacum & DW004611 & $1.12 \mathrm{E}-60$ \\
\hline ACC42 & 2 & ubiquitin extension protein & C. annuum & ABK42077 & $2.29 \mathrm{E}-69$ \\
\hline ACC43 & 2 & wox2 protein & Petunia $\times$ hybrida & ACA64094 & $1.28 \mathrm{E}-42$ \\
\hline \multicolumn{6}{|c|}{ (b) Basal cell } \\
\hline BCC01 & 62 & NADH dehydrogenase subunit 7 & Beta vulgaris & NP_064055 & $1.72 \mathrm{E}-58$ \\
\hline $\mathrm{BCCO} 2$ & 30 & No hit & & & \\
\hline $\mathrm{BCCO}$ & 24 & tabacum cDNA clone mRNA ${ }^{a}$ & N. tabacum & FG626245 & 1.69E-73 \\
\hline $\mathrm{BCCO} 4$ & 20 & hypothetical protein & R. communis & XP_002524507 & $1.46 \mathrm{E}-06$ \\
\hline BCC05 & 16 & pathogenesis-related protein 10 & S. lycopersicum & BAD95797 & $5.62 \mathrm{E}-11$ \\
\hline
\end{tabular}


Table 1 Functional annotation of the differentially expressed contigs with two or more ESTs between the apical cells (a) and basal cells (b) (Continued)

\begin{tabular}{|c|c|c|c|c|c|}
\hline BCCO6 & 15 & cacao cDNA clone mRNA & T. cacao & CU503631 & $9.02 \mathrm{E}-45$ \\
\hline $\mathrm{BCCO}$ & 11 & tabacum cDNA clone mRNA ${ }^{a}$ & N. tabacum & AM836152 & $0.00 \mathrm{E}+00$ \\
\hline BCCO9 & 9 & acyl-COA-binding protein & V. vinifera & XP_002263421 & $3.10 \mathrm{E}-25$ \\
\hline $\mathrm{BCC} 10$ & 8 & eca1 protein & V. vinifera & XP_002275198 & $1.16 \mathrm{E}-27$ \\
\hline $\mathrm{BCC} 12$ & 7 & embryo abundant methyltransferase & P. trichocarpa & XP_002308901 & $4.35 \mathrm{E}-75$ \\
\hline $\mathrm{BCC} 13$ & 7 & sugar transport protein 8 & V. vinifera & XP_002277946 & $1.62 \mathrm{E}-73$ \\
\hline $\mathrm{BCC} 14$ & 6 & tomato cDNA clone mRNA ${ }^{a}$ & L. esculentum & BW690013 & 5.37E-53 \\
\hline $\mathrm{BCC} 15$ & 5 & tabacum cDNA clone mRNA ${ }^{a}$ & N. tabacum & FS398978 & 2.11E-162 \\
\hline $\mathrm{BCC} 16$ & 4 & tabacum cDNA clone mRNA ${ }^{a}$ & N. tabacum & FS395950 & 3.79E-78 \\
\hline $\mathrm{BCC} 17$ & 4 & tabacum cDNA clone mRNA ${ }^{a}$ & N. tabacum & FG623980 & $2.54 \mathrm{E}-102$ \\
\hline $\mathrm{BCC} 18$ & 4 & glutathione s-transferase & N. tabacum & P25317 & $4.85 E-73$ \\
\hline BCC19 & 4 & nucleoside diphosphate kinase & N. tabacum & Q56E62 & $7.50 \mathrm{E}-11$ \\
\hline $\mathrm{BCC} 20$ & 4 & putative glucosyltransferase & L. esculentum & AAL92461 & $3.49 \mathrm{E}-37$ \\
\hline $\mathrm{BCC} 21$ & 4 & hypothetical protein & P. trichocarpa & XP_002330403 & $1.51 \mathrm{E}-22$ \\
\hline BCC23 & 3 & hypothetical protein & V. vinifera & XP_002284032 & $2.71 \mathrm{E}-21$ \\
\hline BCC24 & 3 & hypothetical protein & V. vinifera & XP_002284032 & $2.10 \mathrm{E}-21$ \\
\hline $\mathrm{BCC} 25$ & 3 & defender against cell death 1 & N.suaveolens $\times$ N.tabacum & BAB40808 & $1.06 \mathrm{E}-17$ \\
\hline $\mathrm{BCC} 27$ & 3 & histone h3.3B isoform 2 & C. intestinalis & XP_002131754 & $7.29 \mathrm{E}-22$ \\
\hline BCC28 & 3 & pollen allergen & R. communis & XP_002517629 & $5.29 \mathrm{E}-15$ \\
\hline BCC29 & 3 & acyl-COA-binding protein & V. vinifera & XP_002263421 & $1.39 \mathrm{E}-25$ \\
\hline $\mathrm{BCC} 30$ & 3 & 60 s ribosomal protein $135 \mathrm{a}$ & G. $\max$ & ACU13467 & $1.01 \mathrm{E}-24$ \\
\hline BCC31 & 2 & hypothetical protein & Escherichia & ZP_04532941 & $3.73 \mathrm{E}-10$ \\
\hline $\mathrm{BCC} 32$ & 2 & tabacum cDNA clone mRNA ${ }^{a}$ & N. tabacum & EB431770 & 2.73E-141 \\
\hline $\mathrm{BCC} 33$ & 2 & tabacum cDNA clone mRNA ${ }^{a}$ & N. tabacum & EH623820 & $1.86 \mathrm{E}-137$ \\
\hline $\mathrm{BCC} 34$ & 2 & 60s ribosomal protein 129 & L. esculentum & AAG49033 & $4.56 \mathrm{E}-16$ \\
\hline BCC35 & 2 & hypothetical protein & V. vinifera & CAN81050 & 1.07E-09 \\
\hline $\mathrm{BCC} 37$ & 2 & histone h3 & $\mathrm{N}$. vectensis & XP_001632617 & $1.62 \mathrm{E}-26$ \\
\hline $\mathrm{BCC} 38$ & 2 & No hit & & & \\
\hline ВСС39 & 2 & cell growth defect factor 2 & V. vinifera & XP_002280550 & $6.60 \mathrm{E}-28$ \\
\hline $\mathrm{BCC} 40$ & 2 & tabacum cDNA clone mRNA ${ }^{a}$ & N. tabacum & AM834148 & 3.30E-147 \\
\hline BCC41 & 2 & 40s ribosomal protein s19 & S. tuberosum & ABB87116 & $3.90 \mathrm{E}-28$ \\
\hline $\mathrm{BCC} 42$ & 2 & DNA-directed RNA polymerase ॥ & R. communis & XP_002522014 & $1.67 \mathrm{E}-26$ \\
\hline BCC43 & 2 & nucleoside diphosphate kinase & N. tabacum & Q56E62 & $1.21 \mathrm{E}-21$ \\
\hline $\mathrm{BCC} 44$ & 2 & hypothetical protein & R. communis & XP_002532758 & $1.73 \mathrm{E}-15$ \\
\hline BCC45 & 2 & tabacum cDNA clone mRNA ${ }^{a}$ & N. tabacum & BP530929 & 4.41E-106 \\
\hline $\mathrm{BCC} 46$ & 2 & No hit & & & \\
\hline $\mathrm{BCC} 47$ & 2 & histone h3 & C. clemensi & ACO15671 & $7.43 E-27$ \\
\hline $\mathrm{BCC} 48$ & 2 & tabacum cDNA clone mRNA ${ }^{a}$ & N. tabacum & FS407739 & $2.26 \mathrm{E}-170$ \\
\hline
\end{tabular}

The contigs are sorted according to the number of ESTs.

${ }^{\text {a }}$ The results of BLASTN search.

transcripts displayed expression differences over two fold between the apical and basal cells. Among these tested transcripts, three transcripts (ACC01, ACC12 and ACC13) were expressed specifically (with expression difference more than 100 fold) in the apical cells (Figure 4a, e, f), while other three (BCC05, BCC15 and BCC28) in the basal cells (Figure $5 c, h, j$ ).

Combining the zygotic expression of transcripts with the expression in apical and basal cells, two different expression patterns were observed in the examined transcripts: (i) specifically expressed only in the apical cell (Figure 4d, e, l, m, x) or in basal cell (Figure 5a-c, h, j); (ii) expressed in zygote, and subsequently predominantly in the apical cell (Figure $4 \mathrm{k}, \mathrm{n}, \mathrm{p}$ ) or in the basal cell (Figure 5e, f, l, m). It's very interesting that about one third of the tested transcripts showed only negligible signals in the zygote, while greatly enhanced the expression in one of the daughter cells after zygotic division, suggesting an mechanism controlling specific gene activation in the apical and basal cells for early embryogenesis. 


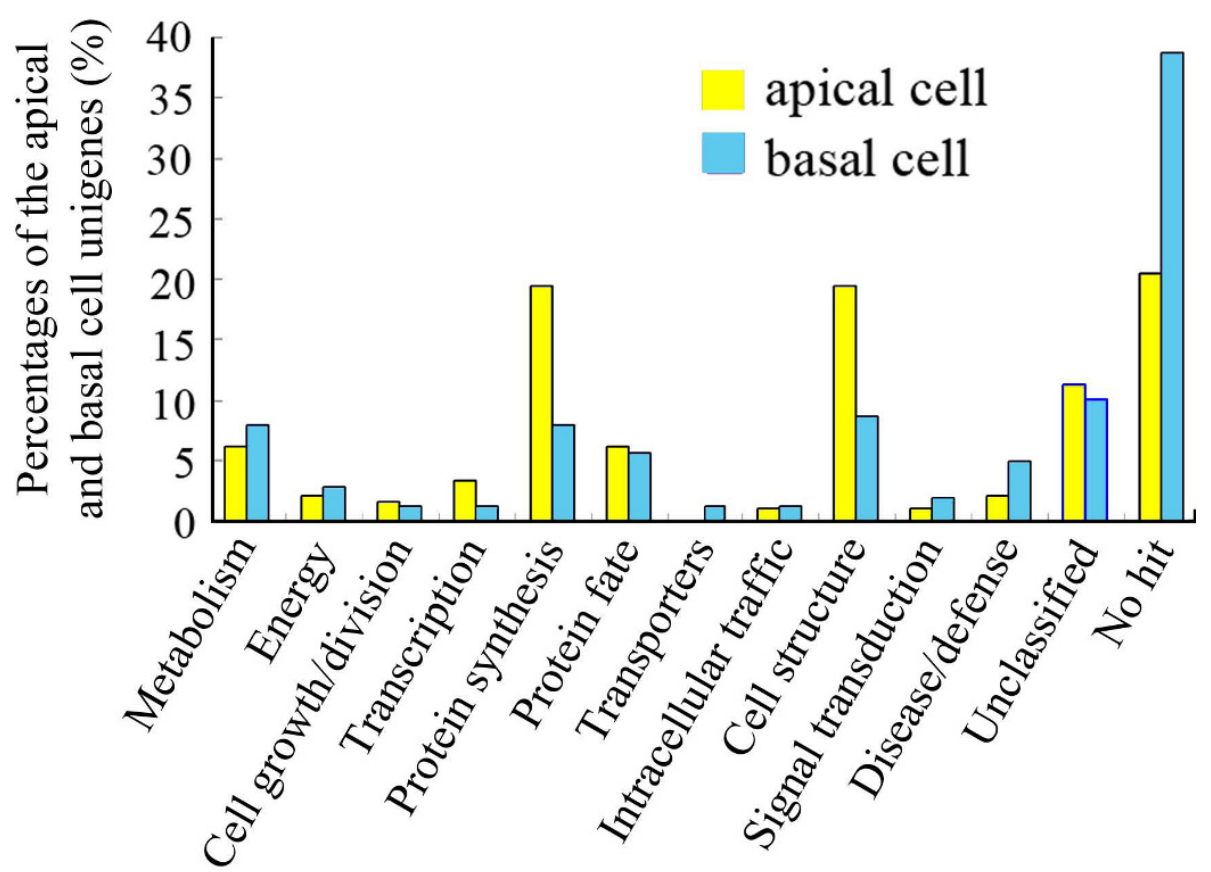

Figure 3 Functional classification of differentially expressed transcripts in apical and basal cells of tobacco two-celled proembryo Percentages of the 167 apical and 131 basal cell unigenes are represented by yellow and blue bars, respectively.

Whole mount in situ hybridization of the isolated zygote and two-celled proembryos

We performed whole mount in situ hybridization in the isolated zygote at the elongated stage and the two-celled proembryo as an additional stringent test to validate our real-time PCR results of differential gene expression in zygote and its two daughter cells. We detected the expression patterns of four candidate genes from apical and basal cell libraries. The results confirmed the expression patterns of SSH identified genes validated by real-time PCR (Figure 6). The signal of AC338C transcript was detected predominantly in the apical pole of zygote and the apical cell of the two-celled proembyo (Figure 6a, b). The expression of AC373C was undetectable in zygote, but specifically initiated expression in the apical daughter cell (Figure 6d, e). For the basal cell transcripts, the expression of $\mathrm{BCC} 04$ was presented exclusively in the basal daughter cell, but not in the zygote and its apical daughter cell (Figure 6g, h). In contrast, BC $335 \mathrm{C}$ transcript displays weak signal in the zygote, while predominant expression in the basal daughter cell (Figure 6j, k). All the two-celled

Table 2 Putative tobacco homologies of Arabidopsis genes involved in normal embryo development

\begin{tabular}{|c|c|c|c|c|}
\hline ID & Chromosome Locus & Gene Symbol & BLAST e-Value/\% Identity/\%\% Similarity & Predicted function \\
\hline ACC26 & At3g04400 & EMB 2171 & $1 \mathrm{e}-80$ 96\% 100\% & Ribosomal Protein L17/L23 \\
\hline ACC 37 & At3g52590 & EMB 2167 & $1 \mathrm{e}-4198 \% 100 \%$ & Ubiquitin Fused to Ribosomal Protein L40 \\
\hline ACC 43 & At5g59340 & WOX2 & $4 \mathrm{e}-1635 \% 46 \%$ & WUSCHEL RELATED HOMEOBOX 2 \\
\hline AC146C & At5g15540 & EMB 2773 & $2 \mathrm{e}-0735 \% 40 \%$ & Adherin sister-chromatid cohesion 2 \\
\hline AC161C & At3g52380 & PDE 322 & $1 e-1533 \% 61 \%$ & Chloroplast RNA Binding Protein \\
\hline AC327C & At2g18510 & EMB 2444 & $2 \mathrm{e}-1036 \% 52 \%$ & Spliceosome Associated Protein \\
\hline AC336C & At2g04030 & EMB 1956 & $4 \mathrm{e}-4955 \% 75 \%$ & Heat Shock Protein (Hsp90) \\
\hline AC338C & At3g11670 & DGD 1 & $4 \mathrm{e}-1050 \% 70 \%$ & Digalactosyl Diacylglycerol Synthase \\
\hline AC349C & At3g52590 & EMB 2167 & $1 e-12$ 39\% 59\% & Ubiquitin Fused to Ribosomal Protein L40 \\
\hline AC364C & At3g11940 & AML 1 & $2 \mathrm{e}-8788 \% 95 \%$ & Ribosomal Protein S5 \\
\hline $\mathrm{BC} 101 \mathrm{C}$ & At5g10480 & PAS 2 & $7 e-3175 \% 87 \%$ & Protein Tyrosine Phosphatase Like \\
\hline $\mathrm{BC} 117 \mathrm{C}$ & At3g54010 & PAS 1 & $2 \mathrm{e}-08$ 33\% 47\% & Immunophilin-like FK506 Binding Protein \\
\hline
\end{tabular}

These sequences were identified by BLASTX search against Arabidopsis sequence database of genes involved in embryogenesis. 


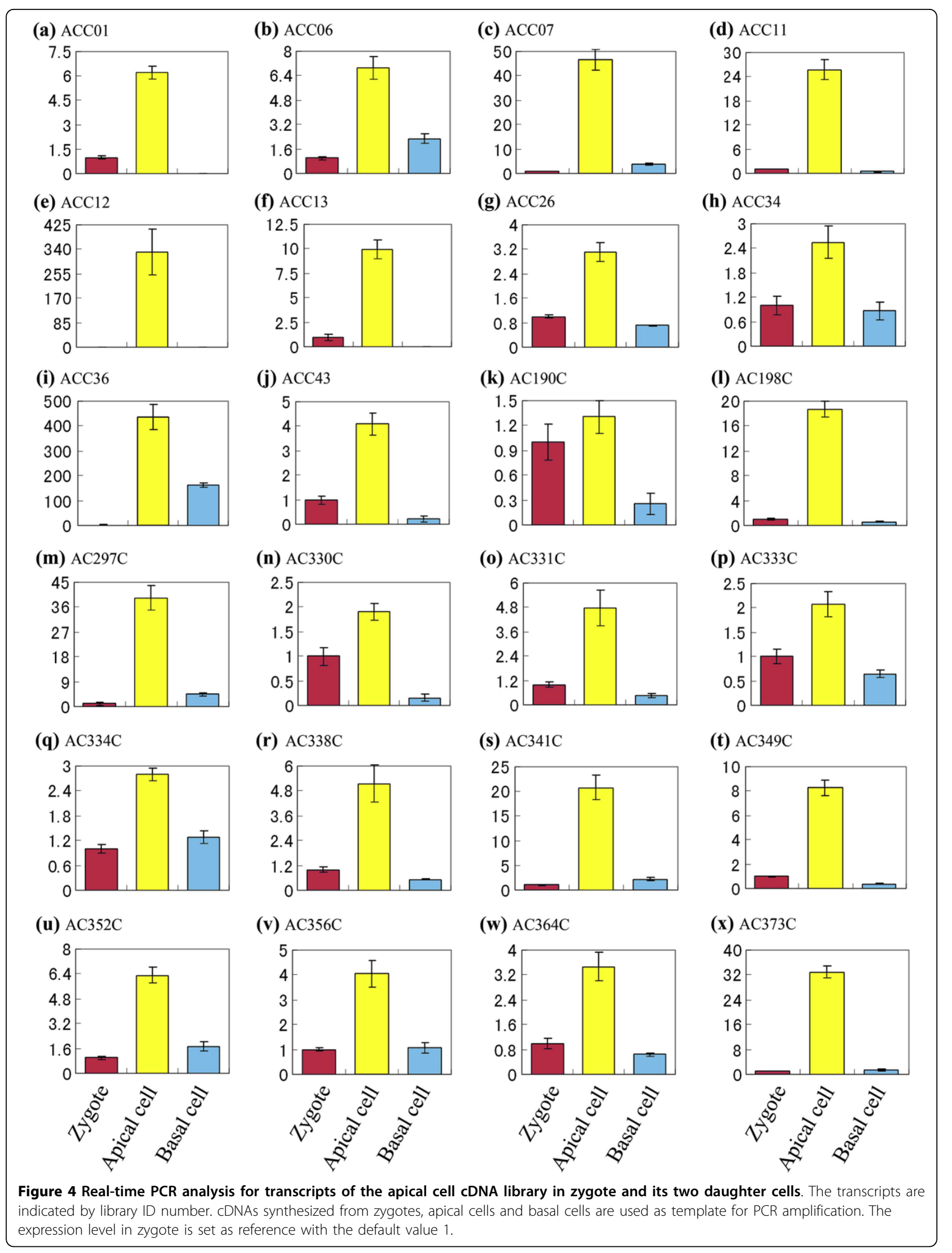




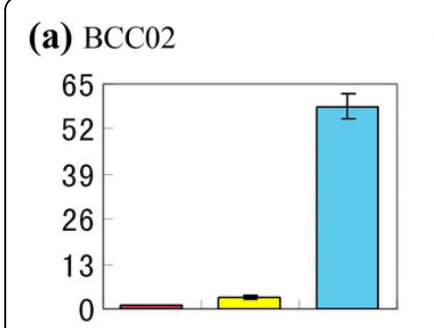

(e) $\mathrm{BCC} 12$

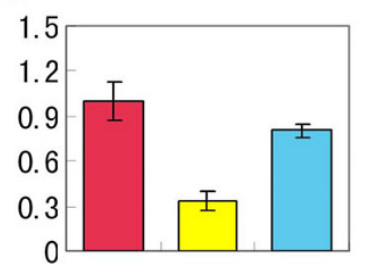

(i) $\mathrm{BCC} 18$

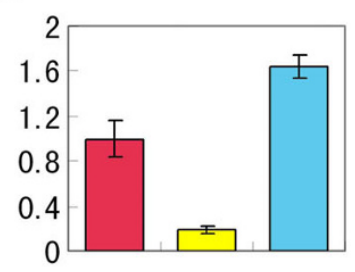

(m) $\mathrm{BC} 335 \mathrm{C}$

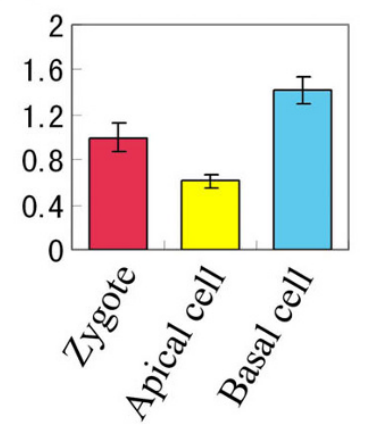

(b) $\mathrm{BCC} 04$

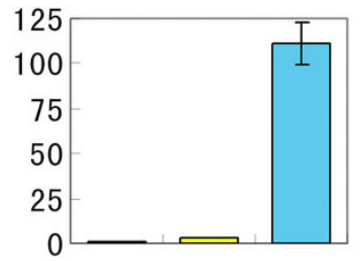

(f) $\mathrm{BCC} 13$

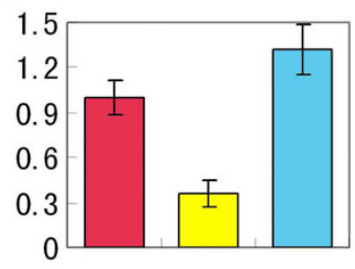

(j) $\mathrm{BCC} 28$

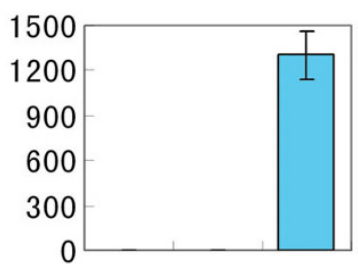

(n) $\mathrm{BC} 336 \mathrm{C}$

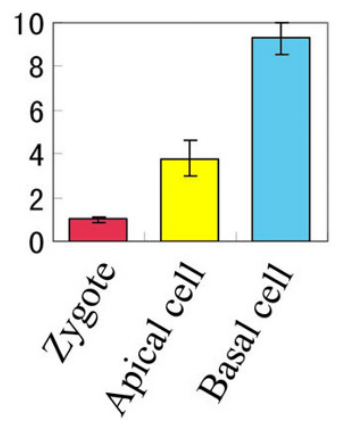

(c) $\mathrm{BCC} 05$

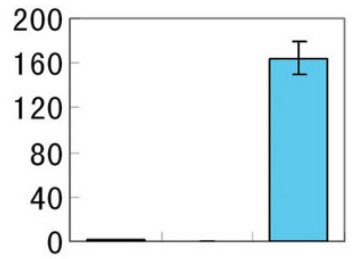

(g) $\mathrm{BCC} 14$

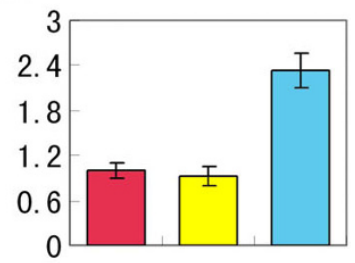

(k) BCC45

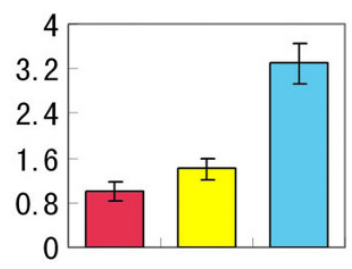

(o) BC379C

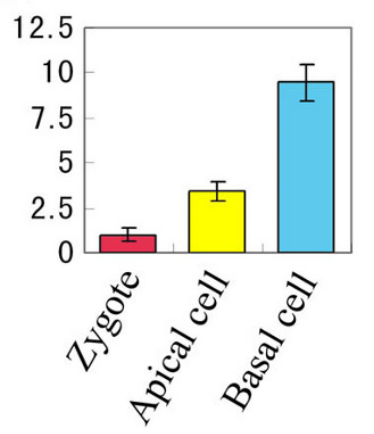

(d) $\mathrm{BCC} 07$

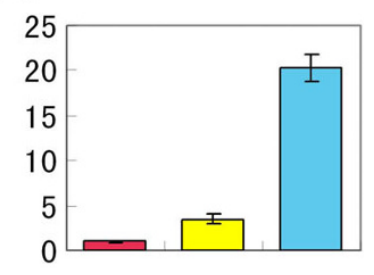

(h) $\mathrm{BCC} 15$

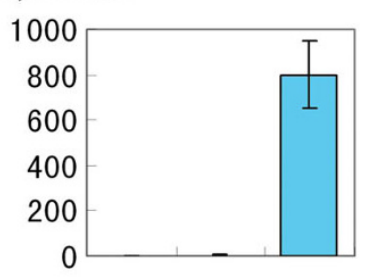

(I) $\mathrm{BC} 321 \mathrm{C}$

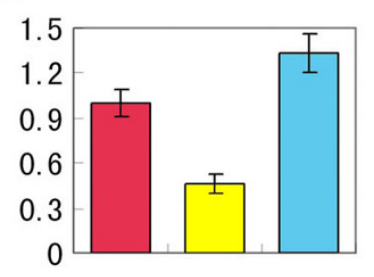

(p) $\mathrm{BC} 388 \mathrm{C}$

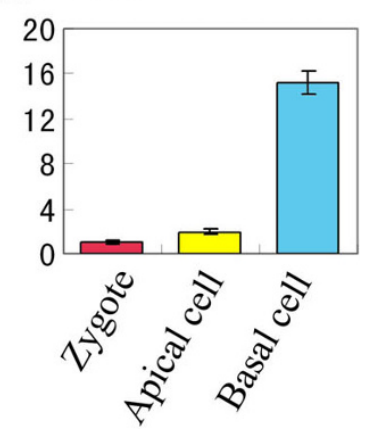

Figure 5 Real-time PCR analysis for transcripts of the basal cell cDNA library in zygote, and its two daughter cells. The transcripts are indicated by library ID number. CDNAs synthesized from zygotes, apical cells and basal cells are used as template for PCR amplification. The expression level in zygote is set as reference with the default value 1.

proembryo samples hybridized with sense probes showed no signal (Figure 6c, f, i, l). These expression data are consistent with the real-time PCR results (Figures 4 and 5).

\section{Expression analysis of candidate genes in different organs} and tissues

We analyzed the expression of the validated differential transcripts in different organs and tissues of tobacco (Figure 7). All of the detected transcripts displayed differential expression in the tested organs and tissues. The four transcripts (ACC34, AC190C, AC373C and $\mathrm{BC} 379 \mathrm{C})$ were expressed at high levels in 1 day after pollination (DAP) ovule and then gradually decreased along with the development of ovules (Figure 7c, d, j, t). Among these transcripts, expression of ACC 34 and BC379C declined immediately after fertilization, suggesting their possible roles in ovule development and fertilization. However, the expressions of two other transcripts $\mathrm{BCC} 04$ and $\mathrm{BC} 388 \mathrm{C}$ were firstly up-regulated after fertilization and then gradually decreased during the maturation of seed. Apart from the expression in ovules, three transcripts (ACC13, BCC05 and $\mathrm{BCC} 18$ ) displayed predominant expression in root, three transcripts (ACC11, BCC07 and BCC14) in stem, and three transcripts (AC198C, AC331C and BC379C) in leaf, 


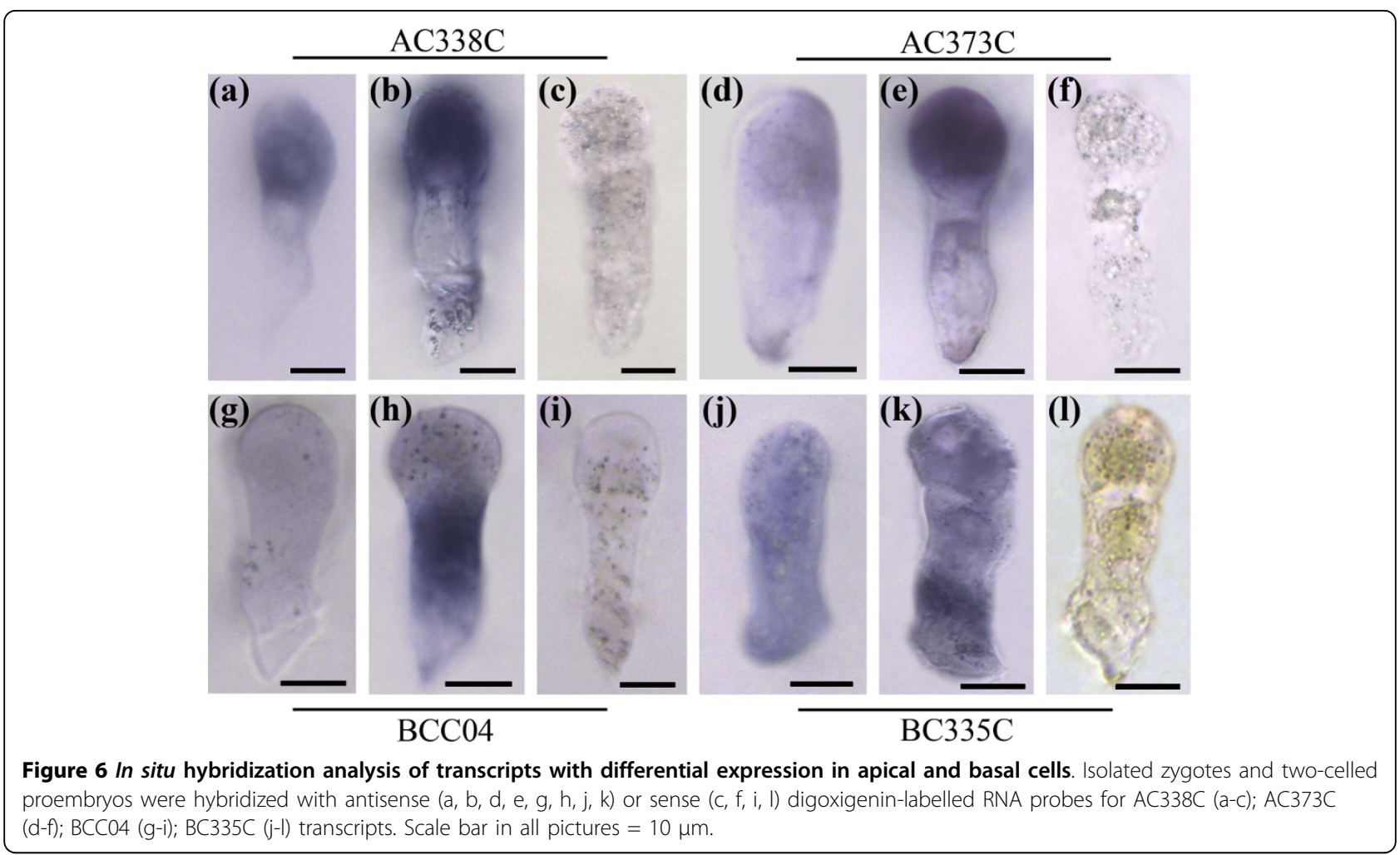

with all nine transcripts showing moderate to weak signal in other organs (Figure 7). Interestingly, the expressions of five transcripts AC334C, AC338C, AC356C, $\mathrm{BCC} 13$ and $\mathrm{BCC} 45$ were abundant in anthers but scarce in ovules and vegetative tissues. Therefore, these results indicate that the apical and basal cell transcripts may play more general roles during plant growth and development.

\section{Discussion}

The apical and basal cells of tobacco two-celled proembryo possess distinct transcriptional profiles

In dicotyledonous plant tobacco, cell division of zygotic embryo follows the same settled pattern as classical model plant Arabidopsis. The zygote firstly undergoes an asymmetric transverse division to shape a two-celled proembryo with a small apical cell and a large basal cell. Up to date, though the two daughter cells from zygote display a lot of differences in morphological characters, the internal molecular differences still remain unknown. Some presented evidences indicate that the two cells could be distinguished by their different gene expression. In scarlet runner bean, G564 and C541 mRNAs are only present in the two basal cell descendants of proembryos at the four-cell stage [37]. In Arabidopsis, some members of WUSCHEL-RELATED HOMEOBOX (WOX) and PIN-FORMED (PIN) genes families as well as Arabidopsis thaliana MERISTEM LAYER 1 (ATML1) gene all displayed specific expression in one of the daughter cells after zygote division [38-40]. Here we for the first time, carried out a comparative transcriptome analysis on the two cells, and successfully identified a lot of differential transcripts in the apical and basal cells. Transcript expression validation by quantitative real time PCR and ISH technique demonstrated that these isolated transcripts displayed a polar distribution in the two-celled proembryos. During these genes, the expression of transcript AC338C appeared in the apical pole of zygotes, and further enhanced in the apical cells (Figure 6). Moreover, the transcripts ACC07, ACC11, ACC12, AC198C, AC297C, AC341C and AC373C were specifically initiated to express in the apical cells, while transcripts $\mathrm{BCC} 02, \mathrm{BCC} 04, \mathrm{BCC} 05, \mathrm{BCC} 15$ and $\mathrm{BCC} 28$ in the basal cells (Figures 4 and 5 ). Considering some negligible signals, several transcripts were identified as apical or basal cell specific genes (Figures $4 \mathrm{a}, \mathrm{e}, \mathrm{f}$ and $5 c, h, j)$. These differences reveal that the two daughter cells possess significantly distinct transcriptional profiles after the first zygotic division (Figure 8).

Zygotic gene activation (ZGA) is a critical event during early embryogenesis, which means the transfer of development control from parents to zygote and embryo. Some evidences substantiate the assumption that ZGA in higher plants occurs shortly after fertilization $[6,33,34,41]$. In our study, some differential transcripts were expressed in zygote and then only in one of 


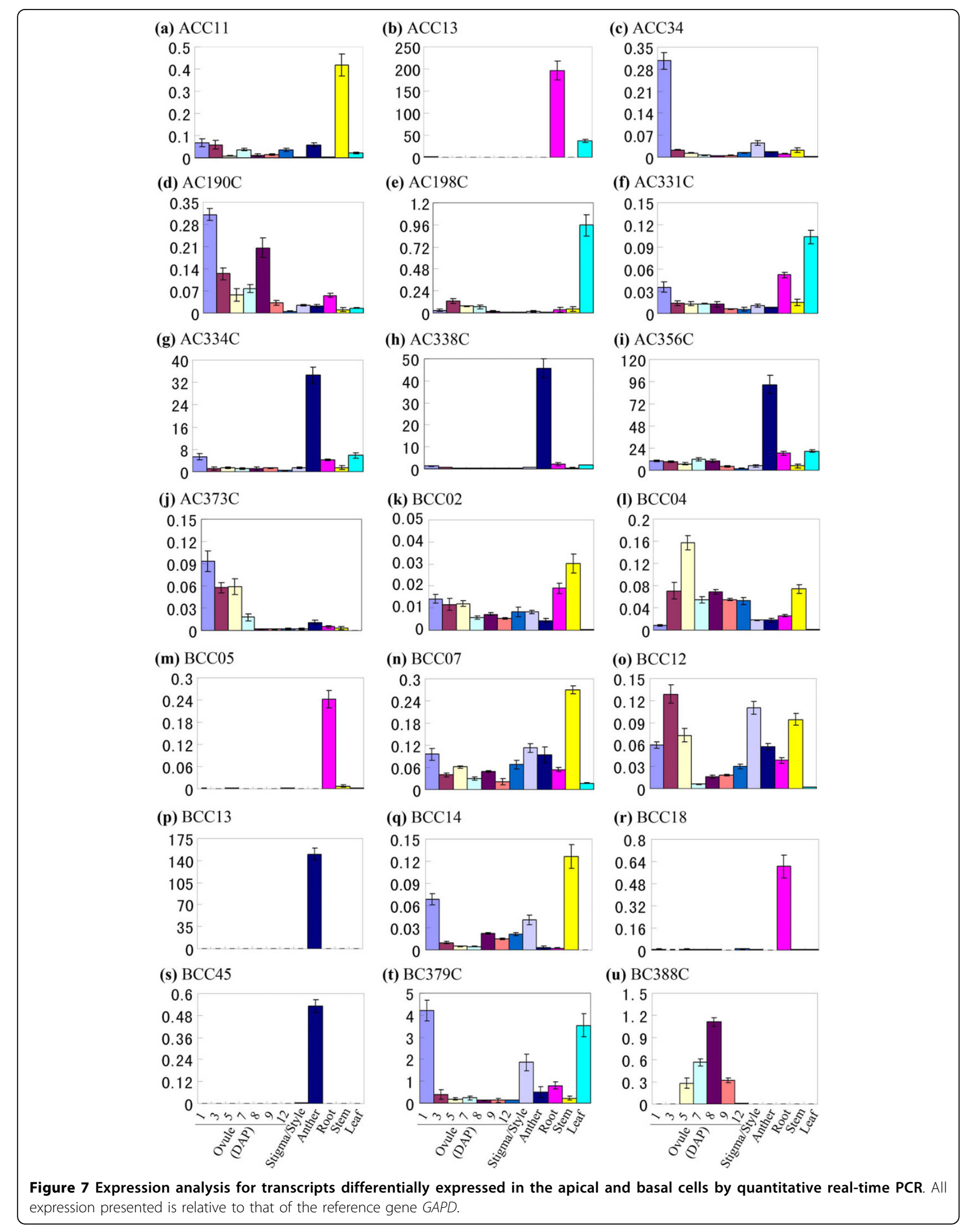


the daughter cells, suggesting the possibility that these transcripts were specifically inherited by the apical or basal daughter cell (Figure 8). The other tested transcripts just displayed weak or negligible expression in zygote, but strong in the apical or basal daughter cell. The results indicate that apart from ZGA, further gene activation in early embryogenesis may also happen in the apical and basal cells, respectively (Figure 8 ). These cell specific transcript inheritation and activation may lead to the transcriptome differences in the apical and basal cells.

Some candidate genes from the apical and basal cells play potential roles in embryo and post-embryo development

It seems that some of the 299 transcripts encode proteins required for gamete and early embryo development based on the homology search against Arabidopsis and rice. As shown in Table 2, 12 transcripts encode homologies of the genes involved in Arabidopsis embryo and seed development, such as PASTICCINO1/2 (PAS1/2) and WOX2. In Arabidopsis, WOX2 and WOX8 genes are expressed complementarily in the apical and basal cells in a lineage-specific manner and regulate respective cell fate decision during early embryogenesis $[39,42]$. Our results show that the tobacco homology of WOX2 (ACC43) is also predominantly expressed in the apical cell of two-celled proembryo. Another apical cell transcript (ACC12), which encodes a tobacco lipid transfer protein, showed specific expression activation in the apical cells. In Arabidopsis embryogenesis, lipid transfer protein gene (AtLTP1) showed a specific position expression in the embryo, with transcript accumulation exclusively in the protodermal cells of the globular embryos and in the cotyledons and the upper end of hypocotyl in late stage of embryos [43].

In the basal cell transcripts, $\mathrm{BCC} 12$ transcript, a putative embryo abundant methyltransferase, displayed predominant expression in zygote and its basal daughter cell (Figure 5). In mouse embryogenesis, histone arginine methylation mediated by arginine methyltransferase 1 (CARM1) contributes to cell fate decision in the fourcell-stage of embryo [44]. Moreover, the mutant analysis for Arabidopsis METHYLTRANSFERASE1 (MET1) and CHROMOMETHYLASE3 (CMT3) gene revels that DNA methylation is critical for the regulation of cell fate decision during early embryogenesis [45]. Besides, the basal cell transcript BCC39 encodes a tobacco homology of the cell growth defect factor 2 (Cdf2) in Arabidopsis [46], and the overexpression of Cdf2 caused Bax-like lethality in yeast [47]. Bax is a mammalian proapoptotic member of the Bcl-2 family, and the overexpression of Bax in Arabidopsis mesophyll protoplasts resulted in cytological apoptosis characteristics [48]. Therefore, such gene may involve in the programmed cell death (PCD) mediated degeneration of the future suspensor (Figure 8).

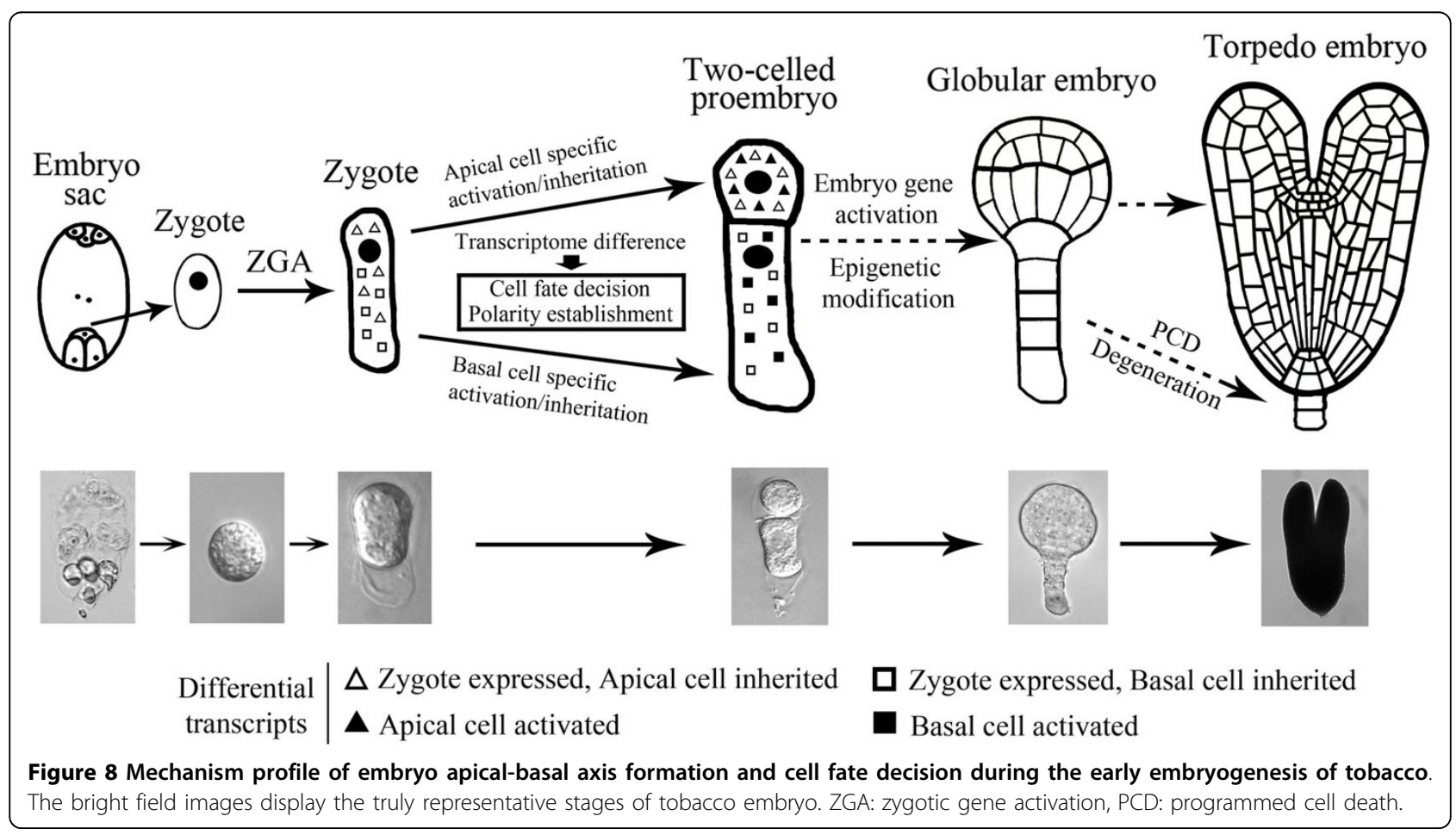


In our study, tissue expression analyses also show that several transcripts are abundant in the different stages of ovules, but barely detectable in vegetative tissues, indicating their possible functions in embryo and ovule development as well as seed formation, such as transcripts ACC34, AC190C, AC373C and BC388C (Figure 7). Besides expression in ovules, five differential transcripts (AC334C, AC338C, AC356C, BCC13 and $\mathrm{BCC} 45)$ in the apical and basal cells displayed predominant expression in mature anthers. In Arabidopsis, the mitogen-activated protein kinase gene $Y D A$ functions in the process of zygote elongation and subsequent cell division, and regulates the first cell fate decision of the basal lineage [6]. Recently, the study reveals that the SHORT SUSPENSOR (SSP) transcripts accumulate in mature pollens, and then are delivered via the sperm cells to zygote, where SSP protein is produced to activate $Y D A$-dependent signalling [41]. On one hand, our anther expressed transcripts may play roles in anther development, and on the other hand, it is reasonable to speculation that these transcripts are transferred to zygote via sperm cells and regulate the subsequent embryo development. Furthermore, another three transcripts (ACC13, BCC05, BCC18) show preponderant expression in tobacco roots (Figure 7). It's well known that auxin is important for pattern formation in embryo and root development $[49,50]$. In our study, one root expressed transcript $\mathrm{BCC} 18$ encodes an auxin induced parA protein in tobacco [51], suggesting that this protein may involve in auxin regulated embryo differentiation and subsequent root formation. Further research of these candidate genes in this study will contribute to elucidate the regulation mechanism of early embryo polarity establishment and pattern formation as well as succedent organ development in higher plants.

\section{Conclusions}

Here we first established a procedure for isolating the live apical and basal cells of tobacco two-celled proembryo just after the first zygotic cell division in vivo. In dicotyledon plant, for the first time, we carried out a global investigation to the transcription profiles of the apical and basal cells in vivo by applying SSH technique coupled with macroarray hybridization. Further validation by quantitative RT-PCR and ISH technique showed that some differential and specific transcripts in the apical and basal cells of two-celled proembryos were successfully isolated, and the differential and specific expression of these transcripts revealed that the transcription compositions in the apical and basal cells are significantly distinct. Transcripts with specific expression in the apical and basal cells provide useful markers for research on the early embryogenesis. Some identified genes specifically expressed in the ovules, suggesting close relation to specific events of the embryo and seed development. Therefore, functional analysis of these genes will promote promising research on molecular mechanism of embryogenesis and seed development.

\section{Methods}

\section{Accession numbers}

All 797 EST sequences in the study (library ID AC001C385C and BC001C-412C) were deposited in GenBank with accession numbers from GT270790 to GT271586.

\section{Isolation of the zygote and the apical and basal cells from the two-celled proembryo}

Tobacco (Nicotiana tabacum cv. SR1) plants were grown in a greenhouse with a photoperiod of $16 \mathrm{~h}$ light/ $8 \mathrm{~h}$ dark at $25-27^{\circ} \mathrm{C}$. The elongated zygotes and the two-celled proembryos were isolated respectively from ovules at 84 and $108 \mathrm{~h}$ after pollination (HAP) according to the method of Qin et al. [12]. The isolated twocelled proembryos were collected into a droplet of $13 \%$ $(\mathrm{w} / \mathrm{v})$ sterile mannitol solution ( $\mathrm{pH}$ 5.7) with a micropipette. To avoid the confusion of apical cells and basal cells from different two-celled proembryos, each proembryo was then transferred into an individual droplet of mannitol solution containing $1 \%$ cellulase onozuka-R10 (Yakult), 0.5\% pectinase (Sigma), 1\% hemicellulase (Sigma) and 0.5\% snailase (Sigma) for enzymolysis. The two-celled proembryos were incubated in the enzyme solution for $10-15 \mathrm{~min}$ at $25^{\circ} \mathrm{C}$. By gently sucking and spitting with a micropipette, a pair of protoplasts with a small apical cell and a large basal cell was separated. The two kinds of protoplasts were respectively collected into fresh $13 \%(\mathrm{w} / \mathrm{v})$ mannitol droplets and washed twice, then transferred into the lysis/binding buffer and immediately frozen in liquid nitrogen. The viability of isolated protoplasts was detected using $50 \mathrm{mg} / \mathrm{L}$ fluorescein diacetate (FDA; Sigma) staining. Two transcription inhibitors, actinomycin D (50 mg/L, Sigma) and cordycepin (100 mg/L, Sigma), proven effective in suppressing the expression of stress-inducible genes [52], were added to all solutions in the process of cell isolation.

\section{RNA isolation of the zygote, apical and basal cells and cDNA synthesis}

For each independent cDNA synthesis, RNA from about two hundred zygotes, three hundred apical cells or basal cells were respectively extracted using the Absolutely RNA Nanoprep Kit (Stratagene) according to the manufacturer's instructions. Then cDNA was synthesized and amplified using a Super SMART PCR cDNA Synthesis Kit (Clontech). The optimal LD-PCR cycle number was determined empirically to ensure the cDNA remained in the exponential phase of amplification. Approximately $100 \mathrm{ng}$ synthesized cDNA was analyzed on a $1.2 \%$ 
agarose gel alongside 100 ng $1 \mathrm{~kb}$ DNA ladder. Then, the amplified cDNAs of the apical and basal cells were used for SSH and templates for gene-specific expression analysis.

\section{Suppression subtractive hybridization}

The generation of forward- and reverse-subtracted cDNA and unsubtracted control cDNA from the apical and basal cells was performed using the PCR-Select cDNA Subtraction Kit (Clontech) following the manufacturer's instructions. Two rounds of hybridization and PCR amplification were performed to enrich the differentially expressed sequences, with 30 fold excess of the driver cDNA to select against for the first round subtraction and 2.5 fold for the second round subtraction. The subtracted apical and basal cell cDNAs were purified using QIAquick PCR Purification Kit (Qiagen), cloned with the pGEM-T Easy Vector System (Promega) and then transformed into Escherichia coli DH5 $\alpha$ cell. The transformed bacteria were plated onto LB agar plates containing ampicillin, X-gal and IPTG. For constructing the subtracted apical and basal cell libraries, 4032 and 3300 recombinant white colonies were picked respectively, and cultured in $80 \mu \mathrm{l}$ LB freezing medium with ampicillin in 384-well microtitre plates. After overnight culture, the plates were stored at $-80^{\circ} \mathrm{C}$ for membrane printing.

\section{Colony and CDNA macroarray preparation}

Colony and cDNA macroarrays were used respectively for the first and second round screenings. For the colony macroarray, all selected clones from subtracted libraries were printed onto Hybond-N+ nylon membranes (Amersham Biosciences) using the Genetix QPix 2 Colony Picker Systems (Genetix Ltd). The nylon membranes were then placed onto LB agar plates with ampicillin and incubated at $37^{\circ} \mathrm{C}$ overnight. For the succedent CDNA macroarray, the first-round validated colonies were picked out for the second round screening with plasmids. The plasmids were isolated from overnight-grown bacterial cultures using a standard alkaline lysis protocol with SDS in 96-well format and then printed onto Hybond-N+ nylon membranes. All the macroarray membranes were treated following the user manuals, with DNA crosslinked to membranes by baking at $80^{\circ} \mathrm{C}$ for $2 \mathrm{~h}$, and then were stored at $-20^{\circ} \mathrm{C}$ for differential screenings.

\section{Preparation of probes and cDNA differential screening}

The probe labeling and macroarray hybridization were carried out using the PCR-select Differential Screening Kit (Clontech). The membranes were prehybridized for $40-60 \mathrm{~min}$ at $72^{\circ} \mathrm{C}$, and then hybridized with the radioactive probes at $72^{\circ} \mathrm{C}$ overnight. The hybridized membranes were washed in $2 \times$ SSC and $0.5 \%$ SDS for $4 \times 20 \mathrm{~min}$, in $0.2 \times \mathrm{SSC}$ and $0.5 \%$ SDS for $2 \times 20 \mathrm{~min}$ at $68^{\circ} \mathrm{C}$, and then exposed to PhosphorImager screens (Amersham Biosciences) for 24 hours. Images were acquired by scanning the membranes with a Typhoon 9210 scanner (Amersham Biosciences), and data analysis was performed using ArrayVision 8.0 software (Amersham Biosciences). The clones showing the most marked differential expression were selected for sequencing.

\section{Sequence and bioinformatics analysis}

The differentially expressed clones identified by screening were picked for sequencing with ABI3730 machines (Applied Biosystems). The vector and adaptor sequences were trimmed using Vector NTI Advance 9 software (Informax). After pre-processing, the expressed sequence tags (ESTs) were clustered and assembled into contigs using online tool EGassembler (http://egassembler.hgc. jp/; [53]). The assembled consensus sequences of contigs and valid ESTs were used as a query for BLASTN and BLASTX searches http://blast.ncbi.nlm.nih.gov/Blast.cgi, with significance threshold score $>115$, expected value $<\mathrm{e}^{-25}$ for BLASTN, and an e-value of $<\mathrm{e}^{-5}$, score $>50$ for BLASTX. Transcripts encoding proteins of known functions were manually categorized into the functional classification described by Bevan et al. [54], with reference to the scarlet runner bean (SRB) embryonic EST project (http://www.mcdb.ucla.edu/Research/ Goldberg).

\section{Gene expression analysis by quantitative real-time PCR}

For expression analysis in the zygote and its two daughter cells, pre-amplified double-stranded cDNAs (ds cDNAs) using the Super SMART PCR cDNA synthesis kit were used. After purification and measurement, $20 \mathrm{ng}$ of ds cDNA from each sample was used as template for real-time PCR analysis by SYBR-green fluorescence using the Rotor-Gene Q6000 system (Corbett Life Science). Cycling parameters were as follows: $94^{\circ} \mathrm{C}$ for $10 \mathrm{sec}, 56^{\circ} \mathrm{C}$ for $20 \mathrm{sec}$, and $72^{\circ} \mathrm{C}$ for $30 \mathrm{sec}$. The cDNA samples used were independent from those of the SSH analysis and all expression patterns were confirmed by using two independent cDNA samples. For every examined gene, the expression levels in each sample relative to zygote were calculated.

For expression pattern analysis among different organs, the materials were taken as follows: root, stem and leaf from the one-month-old plants, anther and stigma/style from anthesis-stage flowers, 1 DAP (day after pollination ) ovules at the egg-celled stage, 3 DAP at the zygote, 5 DAP at early globular embryo, 7 DAP at late globular embryo, $8 \mathrm{DAP}$ at heart-shaped embryo, 9 DAP at torpedo-shaped embryo and 12 DAP at cotyledon-staged embryo. Each reaction contained equal 
amount of sample cDNA, and the reaction was repeated at least twice. The constitutively expressed glyceraldehyde-3-phosphate dehydrogenase (GAPD) gene (Accession number AJ133422) was used as an internal standard. Primer pairs were all designed with Primer Premier Software (Premier Biosoft International) and listed in the Additional file 3.

\section{Whole mount in situ hybridization}

Digoxigeninlabeled RNA probes were generated with the DIG RNA labeling kit (Roche) according to the manufacturer's instructions, and in situ hybridization was performed as described by Hejátko et al. [55], with modification of embedding the isolated zygotes and the two-celled proembryos in $12 \%$ polyacrylamide. The elongated zygotes and the two-celled proembryos were isolated respectively from ovules at 84 and $108 \mathrm{~h}$ after pollination (HAP). Gel pieces containing the zygotes and proembryos after hybridization were incubated in a 1:2000 Anti-DIG-Antibody (Roche), and transcripts were detected colorimetrically by the DIG nucleic acid detection kit (Roche). The images were digitally recorded with a $\mathrm{BH} 2$ microscope (Olympus) and the digital sight DS-U2 camera system (Nikon).

\section{Additional material}

Additional file 1: List of contig EST constitutions after sequence assembly.

Additional file 2: Unigene information list of blast annotation results and function classification.

Additional file 3: List of primers used for real-time PCR analysis of zygote, apical cell, basal cell, organ and tissue specific expression

\begin{abstract}
Acknowledgements
This study was supported by National Natural Science Foundation of China (30970277, 30821064) and the Major State Basic Research Program of China (2007CB108704)

\section{Authors' contributions}

TXH and MY contributed equally in the design and execution of the experiment, and participate in the analyses of the study. TXH drafted the manuscript. JZ conceived of the study, and participated in its design and coordination. All authors contributed to the revision of manuscripts, and approved the final manuscript.
\end{abstract}

Received: 28 June 2010 Accepted: 11 August 2010

Published: 11 August 2010

\section{References}

1. Goldberg RB, De Paiva G, Yadegari R: Plant embryogenesis: Zygote to seed. Science 1994, 266:605-614.

2. West MAL, Harada JJ: Embryogenesis in higher plants: An overview. Plant Cell 1993, 5:1361-1369.

3. van Den Berg C, Weisbeek P, Scheres B: Cell fate and cell differentiation status in the Arabidopsis root. Planta 1998, 205:483-491.

4. Yeung EC, Meinke DW: Embryogenesis in angiosperms: Development of the suspensor. Plant Cell 1993, 5:1371-1381.
5. Hall Q, Cannon MC: The cell wall hydroxyproline-rich glycoprotein RSH is essential for normal embryo development in Arabidopsis. Plant Cell 2002, 14:1161-1172.

6. Lukowitz W, Roeder A, Parmenter D, Somerville C: A MAPKK kinase gene regulates extra-embryonic cell fate in Arabidopsis. Cell 2004, 116:109-119.

7. Mayer U, Buttner $G$, Jürgens $G$ : Apical-basal pattern formation in the Arabidopsis embryo: Studies on the role of the gnom gene. Development 1993, 117:149-162

8. Bouget FY, Gerttula S, Shaw SL, Quatrano RS: Localization of Actin mRNA during the Establishment of Cell Polarity and Early Cell Divisions in Fucus Embryos. Plant Cell 1996, 8:189-201.

9. Corellou F, Coelho SM, Bouget FY, Brownlee C: Spatial re-organisation of cortical microtubules in vivo during polarisation and asymmetric division of Fucus zygotes. J Cell Sci 2005, 118:2723-2734.

10. Goodner B, Quatrano RS: Fucus embryogenesis: a model to study the establishment of polarity. Plant Cell 1993, 5:1471-1481.

11. Kumlehn J, Lörz H, Kranz E: Differentiation of isolated wheat zygotes into embryos and normal plants. Planta 1998, 205:327-333.

12. Qin $Y$, Zhao J: Localization of arabinogalactan proteins in egg cells, zygotes, and two-celled proembryos and effects of $\beta$-D-glucosyl Yariv reagent on egg cell fertilization and zygote division in Nicotiana tabacum L. J Exp Bot 2006, 57:2061-2074.

13. Sauer M, Friml J: In vitro culture of Arabidopsis embryos within their ovules. Plant J 2004, 40:835-843.

14. Supena EDJ, Winarto B, Riksen T, Dubas E, van Lammeren A, Offringa R, Boutilier K, Custers J: Regeneration of zygotic-like microspore-derived embryos suggests an important role for the suspensor in early embryo patterning. J Exp Bot 2008, 59:803-814.

15. Zimmerman JL: Somatic embryogenesis: a model for early development in higher plants. Plant Cell 1993, 5:1411-1423.

16. Goldberg RB, Barker SJ, Perez-Grau L: Regulation of gene expression during plant embryogenesis. Cell 1989, 56:149-160.

17. Topping JF, Agyeman F, Henricot B, Lindsey K: Identification of molecular markers of embryogenesis in Arabidopsis thaliana by promoter trapping. Plant J 1994, 5:895-903

18. Mayer U, Torres-Ruiz RA, Berleth T, Miséra S, Jürgens G: Mutations affecting body organization in the Arabidopsis embryo. Nature 1991, 353:402-407.

19. Meinke DW, Sussex IM: Embryo-lethal mutants of Arabidopsis thaliana. A model system for genetic analysis of plant embryo development. Dev Biol 1979, 72:50-61.

20. Berleth $\mathrm{T}$, Jürgens $\mathrm{G}$ : The role of the Monopteros gene in organising the basal body region of the Arabidopsis embryo. Development 1993, 118:575-587.

21. Hamann T, Mayer U, Jürgens $G$ : The auxin-insensitive bodenlos mutation affects primary root formation and apical-basal patterning in the Arabidopsis embryo. Development 1999, 126:1387-1395.

22. Long JA, Woody S, Poethig S, Meyerowitz EM, Barton MK: Transformation of shoots into roots in Arabidopsis embryos mutant at the TOPLESS locus. Development 2002, 129:2797-2806

23. Vernon DM, Meinke DW: Embryogenic transformation of the suspensor in twin, a polyembryonic mutant of Arabidopsis. Dev Biol 1994, 165:566-573.

24. Casson S, Spencer M, Walker K, Lindsey K: Laser capture microdissection for the analysis of gene expression during embryogenesis of Arabidopsis. Plant J 2005, 42:111-123.

25. Spencer M, Casson S, Lindsey K: Transcriptional profiling of the Arabidopsis embryo. Plant Physiol 2007, 143:924-940.

26. Fu CM, Sun MX, Zhou C, Yang HY: Isolation of fertilized embryo sacs and zygotes and triggering of zygote division in vitro in Nicotiana tabacum. Acta Bot $\sin 1996,38: 262-267$

27. Holm PB, Knudsen S, Mouritzen P, Negri D, Olsen FL, Roue C: Regeneration of fertile barley plants from mechanically isolated protoplasts of the fertilized egg cell. Plant Cell 1994, 6:531-543.

28. Kranz $\mathrm{E}$, Bautor J, Lörz H: In vitro fertilization of single, isolated gametes of maize mediated by electrofusion. Sex Plant Reprod 1991, 4:12-16.

29. Zhao J, Zhou C, Yang HY: Isolation and in vitro culture of zygotes and central cells of Oryza sativa L. Plant Cell Rep. 2000, 19:321-326.

30. Dresselhaus T, Lörz H, Kranz E: Representative cDNA libraries from few plant cells. Plant J 1994, 5:605-610.

31. Kumlehn J, Kirik V, Czihal A, Altschmied L, Matzk F, Lörz H, Bäumlein H: Parthenogenetic egg cells of wheat: cellular and molecular studies. Sex Plant Reprod 2001, 14:239-243. 
32. Lê Q, Gutièrrez-Marcos JF, Costa LM, Meyer S, Dickinson HG, Lörz H, Kranz E, Scholten S: Construction and screening of subtracted cDNA libraries from limited populations of plant cells: a comparative analysis of gene expression between maize egg cells and central cells. Plant J 2005, 44:167-178.

33. Ning J, Peng XB, Qu LH, Xin HP, Yan TT, Sun MX: Differential gene expression in egg cells and zygotes suggests that the transcriptome is restructed before the first zygotic division in tobacco. FEBS Lett 2006, 580:1747-1752.

34. Sprunck S, Baumann U, Edwards K, Langridge P, Dresselhaus T: The transcript composition of egg cells changes significantly following fertilization in wheat (Triticum aestivum L.). Plant J 2005, 41:660-672.

35. Okamoto T, Scholten S, Lörz H, Kranz E: Identification of genes that are up- or down-regulated in the apical or basal cell of maize two-celled embryos and monitoring their expression during zygote development by a cell manipulation- and PCR-based approach. Plant Cell Physiol 2005, 46:332-338.

36. Schel JHN, Kieft $H$, van Lammeren AAM: Interactions between embryo and endosperm during early developmental stage of maize caryopses (Zea mays). Can J Bot 1984, 62:2842-2853.

37. Weterings K, Apuya NR, Bi Y, Fischer RL, Harada JJ, Goldberg RB: Regional localization of suspensor mRNAs during early embryo development. Plant Cell 2001, 13:2409-2425.

38. Lu PZ, Porat R, Nadeau JA, O'Neill SD: Identification of a meristem L1 layer-specific gene in Arabidopsis that is expressed during embryonic pattern formation and defines a new class of homeobox genes. Plant Cell 1996, 8:2155-2168.

39. Haecker A, Gross-Hardt R, Geiges B, Sarkar A, Breuninger H, Herrmann M, Laux T: Expression dynamics of WOX genes mark cell fate decisions during early embryonic patterning in Arabidopsis thaliana. Development 2004, 131:657-668

40. Friml J, Vieten A, Sauer M, Weijers D, Schwarz H, Hamann T, Offringa R, Jürgens G: Efflux-dependent auxin gradients establish the apical-basal axis of Arabidopsis. Nature 2003, 426:147-153.

41. Bayer M, Nawy T, Giglione C, Galli M, Meinnel T, Lukowitz W: Paternal control of embryonic patterning in Arabidopsis thaliana. Science 2009, 323:1485-1488.

42. Breuninger $H$, Rikirsch $E$, Hermann M, Ueda M, Laux T: Differential expression of WOX genes mediates apical-basal axis formation in the Arabidopsis embryo. Dev Cell 2008, 14:867-876.

43. Vroemen CW, Langeveld S, Mayer U, Ripper G, Jürgens G, Van Kammen A De Vries SC: Pattern formation in the Arabidopsis embryo revealed by position-specific lipid transfer protein gene expression. Plant Cell 1996, 8:783-791.

44. Torres-Padilla ME, Parfitt DE, Kouzarides T, Zernicka-Goetz M: Histone arginine methylation regulates pluripotency in the early mouse embryo. Nature 2007, 445:214-218.

45. Xiao WY, Custard KD, Brown RC, Lemmon BE, Harada JJ, Goldberg RB, Fischer RL: DNA methylation is critical for Arabidopsis embryogenesis and seed viability. Plant Cell 2006, 18:805-814.

46. Kawai-Yamada M, Saito $Y$, Jin L, Ogawa T, Kim KM, Yu LH, Tone Y, Hirata A, Umeda M, Uchimiya H: A novel Arabidopsis gene causes Bax-like lethality in Saccharomyces cerevisiae. J Biol Chem 2005, 280:39468-39473.

47. Kim KM, Jun DY, Kim SK, Kim CK, Kim BO, Kim YH, Park W, Sohn JK, Hirata A, Kawai-Yamada M, Uchimiya H, Kim DH, Sul IW: Identification of novel mitochondrial membrane protein (Cdf3) from Arabidopsis thaliana and its functional analysis in a yeast system. J Microbiol Biotechnol 2007, 17:891-896.

48. Baek D, Nam J, Koo YD, Kim DH, Lee J, Jeong JC, Kwak SS, Chung WS, Lim CO, Bahk JD, Hong JC, Lee SY, Kawai-Yamada M, Uchimiya H, Yun DJ: Bax-induced cell death of Arabidopsis is meditated through reactive oxygen-dependent and -independent processes. Plant Mol Biol 2004, 56:15-27.

49. Weijers D, Sauer M, Meurette O, Friml J, Ljung K, Sandberg G, Hooykaas P, Offringa R: Maintenance of embryonic auxin distribution for apical-basal patterning by PIN-FORMED-dependent auxin transport in Arabidopsis. Plant Cell 2005, 17:2517-2526.

50. Blilou I, Xu J, Wildwater M, Willemsen V, Paponov I, Friml J, Heidstra R, Aida M, Palme K, Scheres B: The PIN auxin efflux facilitator network controls growth and patterning in Arabidopsis roots. Nature 2005, 433:39-44.
51. Takahashi Y, Kuroda H, Tanaka T, Machida Y, Takebe I, Nagata T: Isolation of an auxin-regulated gene cDNA expressed during the transition from $\mathrm{G}_{0}$ to $S$ phase in tobacco mesophyll protoplasts. Proc Natl Acad Sci USA 1989, 86:9279-9283.

52. Leonhardt N, Kwak JM, Robert N, Waner D, Leonhardt G, Schroeder II: Microarray expression analyses of Arabidopsis guard cells and isolation of a recessive abscisic acid hypersensitive protein phosphatase $2 \mathrm{C}$ mutant. Plant Cell 2004, 16:596-615.

53. Masoudi-Nejad A, Tonomura K, Kawashima S, Moriya Y, Suzuki M, Itoh M, Kanehisa M, Endo T, Goto S: EGassembler: online bioinformatics service for large-scale processing, clustering and assembling ESTs and genomic DNA fragments. Nucleic Acids Res 2006, 34:W459-462.

54. Bevan M, Bancroft I, Bent E, Love K, Goodman H, Dean C, Bergkamp R, Dirkse W, Van Staveren M, Stiekema W, Drost L, Ridley P, Hudson SA, Patel K, Murphy G, Piffanelli P, Wedler H, Wedler E, Wambutt R, Weitzenegger T, Pohl TM, Terryn N, Gielen J, Villarroel R, De Clerck R, Van Montagu M, Lecharny A, Auborg S, Gy I, Kreis M, et al: Analysis of $1.9 \mathrm{Mb}$ of contiguous sequence from chromosome 4 of Arabidopsis thaliana. Nature 1998, 391:485-488.

55. Hejátko J, Blilou I, Brewer PB, Friml J, Scheres B, Benková E: In situ hybridization technique for mRNA detection in whole mount Arabidopsis samples. Nat Protoc 2006, 1:1939-1946.

doi:10.1186/1471-2229-10-167

Cite this article as: Hu et al:: Comparative transcriptional profiling analysis of the two daughter cells from tobacco zygote reveals the transcriptome differences in the apical and basal cells. BMC Plant Biology 2010 10:167.

\section{Submit your next manuscript to BioMed Central and take full advantage of:}

- Convenient online submission

- Thorough peer review

- No space constraints or color figure charges

- Immediate publication on acceptance

- Inclusion in PubMed, CAS, Scopus and Google Scholar

- Research which is freely available for redistribution
C Biomed Central 